\title{
Role of Pharmacists in National Public Health Programs in India: A Survey on Pharmacy Students' Perceived Knowledge and Attitude
}

\author{
Siva Prasada Reddy Maddirala Venkata ${ }^{1}$, Peter Kielgast ${ }^{2}$, Ubaidulla Udhumansha ${ }^{3}$, and \\ Marja Airaksinen ${ }^{1}$
}

1'Division of Pharmacology and Pharmacotherapy, Clinical Pharmacy Group, University of Helsinki, Finland. 2Division of Community Pharmacy, Proprietor Pharmacist, Taastrup Pharmacy, Taastrup Hovedgade 60, Taastrup, DK-263, Denmark. ${ }^{3}$ Department of Pharmaceutics, C. L. Baid Metha College of Phrmacy, Jyothi Nagar, Rajiv Gandhi Salai, Thorapakkam, Chennai- 600 097, India.

\begin{abstract}
Objective: An attempt was made to explore the awareness, perceived knowledge and attitude of Indian pharmacy students on National Public Health Programs (NPHPs). Methods: This study was a cross-sectional classroom survey among final year D Pharm, B Pharm and Pharm D students in India. A survey tool was prepared to assess: (i) pharmacy students' perceived knowledge and attitude towards NPHPs in general; (ii) perceived knowledge on individual NPHPs. The survey tool was distributed to 326 students from 5 randomly selected pharmacy colleges from South India. A brief introduction on NPHPs and study objectives were provided to students and were instructed to respond independently. Results: Of all respondents ( $n=326), 83 \%$ had opined that it was very important/important to include NPHPs in normal pharmacists' training programs. In comparison to D Pharm and B Pharm, a higher proportion of Pharm D students estimated that they knew well/knew to some extent about NPHPs $(55 \%$ vs, $39 \%$ vs. $68 \%$, respectively, $\mathrm{p}=<0.001)$. DPharm and Pharm D students indicated higher interest in NPHPs than B Pharm students. Of B Pharm respondents $65 \%$ were willing to take up a professional role in NPHPs, whereas $82 \%$ DPharm and $85 \%$ Pharm D ( $p=0.001)$. Of all student groups, only $21 \%$ believed that their current knowledge was very much sufficient/sufficient to become active part of NPHPs. $81 \%$ students felt that they have very important/important role to play in NPHPs and $96 \%$ were willing to take up a professional role and want to learn more about NPHPs. Conclusion: Students had positive attitudes on pharmacists' involvement in NPHPs, although their attitudes varied in different student groups, Pharm D and D Pharm students being most positive towards involvement in NPHPs. The study also revealed the need for increasing contents supporting NPHPs to all pharmacy programs, particularly to B Pharm program. There is scope for detailed national level analysis to identity pharmacists potential in NPHPs.
\end{abstract}

Key words: Pharmacy Education, Pharmacy Students, Knowledge and Attitude, Public Health, Pharmacist role in public health.

\section{INTRODUCTION}

According to WHO's World Health Report 2006, there are at least 57 countries in the world with a critical shortage of health care workers. ${ }^{1,2}$ India has a severe shortage of human resources for health ${ }^{3} \mathrm{~A}$ joint document, "Developing pharmacy practice: a focus on patient care" by International Pharmaceutical Federation (FIP) and WHO emphasize that pharmacists should engage in preventive care activities that promote public health and prevent disease. ${ }^{4}$ However, for decades the health and pharmaceutical policies of India have overseen human resources readily available in phar-

\section{Submission Date : 03-12-2014 \\ Revision Date : :22-06-2015 \\ Accepted Date : :19-07-2015}

DOI: $10.5530 /$ ijper.50.1.8

Correspondence Address Peter Kielgast, PhD

Division of Community

Pharmacy, Proprietor

Pharmacist, Taastrup

Pharmacy

Taastrup Hovedgade 60,

Taastrup, DK-2630,

Denmark.

Tel: +45-4399 0098

E-mail: taastrup@apoteket.dk

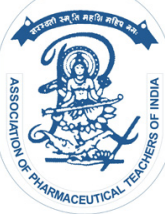

www.ijper.org 
macy profession. The Indian public health standards formulated by the National Rural Health Mission (NRHM) do not place much emphasis on the role of pharmacists as compared to other categories of personnel, such as nurses and laboratory technicians. ${ }^{5}$ In the last decade, pharmacy profession has seen enormous growth due to sincere efforts by the Pharmacy Council of India and private institutions. There are about 717 colleges conducting D Pharm, 968 colleges conducting B Pharm and 160 colleges conducting Pharm D and Pharm D (Post Baccalaureate) programs in India, ${ }^{6,7}$ having provision for over 100,000 pharmacy admissions each year. ${ }^{7}$ India has over a million registered pharmacists. These large numbers are being used by health authorities to show improved and better statistics of health and medical personnel, but not being used in public health policies and patient care practice settings. Glaring example for this is that pharmacists are not mentioned in national health and pharmaceutical policies. In the worldwide scenario, pharmacists offer public health interventions more conveniently than other paramedics since they are easily accessible and recognized as experts in matters of health ${ }^{8}$ and medicine, which should be adopted by Indian pharmacy profession.

The government of India runs several national public health programs (NPHPs) such as HIV/AIDS control, Tuberculosis control, Vector Borne disease control, Leprosy eradication, Pulse polio, Universal vaccination and Tobacco eradication programs. ${ }^{9}$ Pharmacists could contribute to public health and patient care through these programs. A prerequisite for their contributions is that they are trained about NPHPs during their undergraduate studies. India has three pharmacy programs, D Pharm, B Pharm and Pharm D. ${ }^{10}$ The public health system has a shortage of medical and paramedical personnel. Government estimates (based on vacancies in sanctioned posts) indicate that $18 \%$ of primary health centers are without a doctor, about $38 \%$ are without a laboratory technician, and $16 \%$ are without a pharmacist. ${ }^{11}$

\section{OBJECTIVE}

The objective of this study was to explore final year D Pharm, B Pharm and Pharm D students' awareness, perceived knowledge and attitude, and acquaintance with 11 major National Public Health Programs (NPHPs) and their attitude towards pharmacists' involvement in public health and patient care.

\section{STUDY DESIGN}

The study was conducted as a cross-sectional classroom survey in 2014. A survey instrument with 27 items was formulated by taking "A Survey Exploring Knowledge and Perceptions of General Practitioners Towards the Use of Generic Medicines in the Northern State of Malaysia"12 and "Pharmacy Students' Perspectives on a PharmD/MPH Dual Degree Program at a Large Metropolitan School of Pharmacy", ${ }^{13}$ as main references. The survey instrument assessed pharmacy students' in: (i) perceived knowledge and attitude on National Public Health Programs in general; and (ii) perceived knowledge on individual National Public Health Programs. (iii) The students were asked to give their top two preferences of work area (job discipline) after completion of their pharmacy education.

The following 11 major programs ${ }^{10}$ as prioritized by the Ministry of Health and Family Welfare, Government of India, were included in the survey instrument: (1) HIV/ AIDS control; (2) Revised National Tuberculosis Control (RNTCP); (3) Vector Borne Disease Control (NVBDCP); (4) Leprosy Eradication (NLEP); (5) National Mental Health (NMPH); (6) Prevention and Control of Deafness (NPPCD); (7) Control of Blindness (NPCB); (8) Pulse Polio; (9) Universal Immunization (UIP); (10) Tobacco Control (NTCP); and (11) Health Care of the Elderly (NPHCE).

The questionnaire was initially validated by two professors, two pharmacists and 6 students for contents before data collection. The survey instrument was distributed to students from 5 randomly selected pharmacy colleges from Southern part of India. A brief introduction on NPHPs and objectives of the study were provided to students. The survey was conducted among D Pharm ( $2^{\text {nd }}$ year $), B$ Pharm ( $4^{\text {th }}$ year $)$ and PharmD ( $6^{\text {th }}$ year $)$ students. This was a classroom survey, students independently responded to the questionnaire in classrooms. The data were collated and analyzed by using SAS (version 9.3). Chi-square tests were used to determine any statistical differences in responses between various student groups with $p$ value of $<0.5$ deemed as significant. The study did not need Ethical Committee approval as per the University of Helsinki Ethical guidelines. However, all the students in-principle agreed to complete the survey tool. The anonymity of the responding students was assured in all phases of the study.

\section{RESULTS}

Among total of 326 responding students, 159 (49\%) were male and 167 (51\%) female students from final 


\begin{tabular}{|c|c|c|c|c|c|}
\hline Variable & $\begin{array}{c}\text { D Pharm } \\
(n=101)\end{array}$ & $\begin{array}{c}\text { B Pharm } \\
(n=109)\end{array}$ & $\begin{array}{c}\text { Pharm D } \\
(n=116)\end{array}$ & $\begin{array}{c}\text { Total } \\
(n=326)\end{array}$ & p-value* \\
\hline $\begin{array}{c}\text { Gender, } \mathrm{n}(\%) \\
\text { Male } \\
\text { Female }\end{array}$ & $\begin{array}{l}57(56) \\
44(44)\end{array}$ & $\begin{array}{l}56(51) \\
53(49)\end{array}$ & $\begin{array}{l}46(39) \\
70(61)\end{array}$ & $\begin{array}{l}159(49) \\
167(51)\end{array}$ & 0.032 \\
\hline $\begin{array}{c}\text { Age } \\
\text { Mean (SD) } \\
\text { Median } \\
\text { Min;max }\end{array}$ & $\begin{array}{c}20.9(1.9) \\
21 \\
18 ; 27\end{array}$ & $\begin{array}{c}21.1(1.2) \\
21 \\
20 ; 29\end{array}$ & $\begin{array}{c}22.8(1.5) \\
23 \\
20 ; 29\end{array}$ & $\begin{array}{c}21.6(1.8) \\
21 \\
18 ; 29\end{array}$ & - \\
\hline
\end{tabular}

\begin{tabular}{|c|c|c|c|c|c|c|c|c|}
\hline \multirow{3}{*}{\begin{tabular}{l}
\multicolumn{1}{c}{ Question } \\
Where do you plan to work \\
after graduation?
\end{tabular}} & \multicolumn{8}{|c|}{ Response, n (\%) } \\
\hline & \multicolumn{2}{|c|}{ Total $(n=326)$} & \multicolumn{2}{|c|}{ D Pharm (n=101) } & \multicolumn{2}{|c|}{ B Pharm $(n=109)$} & \multicolumn{2}{|c|}{ Pharm D (n=116) } \\
\hline & $1^{\text {st }}$ & $2^{\text {nd }}$ & $1^{\text {st }}$ & $2^{\text {nd }}$ & $1^{\text {st }}$ & $2^{\text {nd }}$ & $1^{\text {st }}$ & $2^{\text {nd }}$ \\
\hline Community Pharmacy & $64(20)$ & $40(12)$ & $8(8)$ & $14(14)$ & $27(25)$ & $15(14)$ & $29(25)$ & $11(9)$ \\
\hline Hospital Pharmacy & $76(23)$ & $50(15)$ & $31(31)$ & $8(8)$ & $18(17)$ & $21(19)$ & $27(23)$ & $21(18)$ \\
\hline Drug Manufacturing Industry & $71(22)$ & $34(10)$ & $28(28)$ & $10(10)$ & $25(23)$ & $13(12)$ & $18(16)$ & $11(9)$ \\
\hline Research and Development & $20(6)$ & $19(6)$ & $8(8)$ & $4(4)$ & $12(11)$ & $9(8)$ & $0(0)$ & $6(5)$ \\
\hline Clinical Research & $33(10)$ & $40(12)$ & $2(2)$ & $4(4)$ & $4(4)$ & $9(8)$ & $27(23)$ & $27(23)$ \\
\hline Regulatory affairs in industry & $10(3)$ & $19(6)$ & $2(2)$ & $9(9)$ & $5(5)$ & $4(4)$ & $3(3)$ & $6(5)$ \\
\hline $\begin{array}{l}\text { Regulatory officer in } \\
\text { government }\end{array}$ & $8(2)$ & $21(6)$ & $1(1)$ & $6(6)$ & $0(0)$ & $7(6)$ & $7(6)$ & $8(7)$ \\
\hline Higher studies & $26(8)$ & $38(12)$ & $15(15)$ & $14(14)$ & $8(7)$ & $18(17)$ & $3(3)$ & $6(5)$ \\
\hline Marketing & $10(3)$ & $24(7)$ & $0(0)$ & $15(15)$ & $9(8)$ & $7(6)$ & $1(1)$ & $2(2)$ \\
\hline Teaching & $3(1)$ & $34(10)$ & $2(2)$ & $10(10)$ & $1(1)$ & $6(6)$ & $0(0)$ & $18(16)$ \\
\hline Any other, please specify & $5(2)$ & $7(12)$ & $4(4)$ & $7(7)$ & $0(0)$ & $0(0)$ & $1(1)$ & $0(0)$ \\
\hline
\end{tabular}

year D Pharm ( $\mathrm{n}=101)$, B Pharm $(\mathrm{n}=109)$; and Pharm D $(n=116)$ program in India (Table 1). Their top 3 'first preferences of work area' after completion education were: hospital ( $23 \%$ of the respondents prioritizing this as the first preference of work area), drug manufacturing industry $(22 \%)$ and community pharmacy $(20 \%)$ (Table 2$)$.

\section{Pharmacy students' attitude and perceived knowledge in National Public Health Programs}

Table 3 shows students' perceptions on their knowledge in national public health programs (NPHPs). There was common $100 \%$ agreement on the necessity for the pharmacists to know about NPHPs. Most (69\%) of the students reported having studied about disease prevention and dissemination of information, but only $28 \%$ felt that the amount of time devoted to learn public health aspects in basic pharmacy studies was sufficient. Sixtyseven percent of the students had not studied National Health Policy and 60\% had not studied pharmaceutical policy in pharmacy curriculum. Most typically, training was through some lectures during the basic studies (36\% of the respondents) or self-study (21\%). A small proportion of the students (4\%) had received at least one course on NPHPs in continuing education. Of total 326 respondents, $58 \%$ reported that they had adequate knowledge to take part in NPHPs. The proportion of students reporting adequate knowledge to take part in NPHPs was highest among Pharm D (66\%) and D Pharm (62\%) students and lowest among B Pharm students $(45 \%, \mathrm{p}<0.001)$. The same trend was found in assessing students knowing about NPHPs in India: $41 \%$ of Pharm D students reported knowing NPHPs well, but only $17 \%$ and $10 \%$ of D Pharm and B Pharm students, respectively $(\mathrm{p}<0.001)$.

Of all respondents, $83 \%$ ( $91 \%$ of Pharm D, $90 \%$ of D Pharm and 69\% of B Pharm students; $\mathrm{p}=<0.001$ ) had the opinion that it was very important or important to include NPHPs in normal training programs for pharmacists (Table 4). Only 21\% ( $\mathrm{p}=0.001)$ of the 
Table 3: Pharmacy students' ( $n=326)$ perceived knowledge in NPHPs stratified by pharmacy program

\begin{tabular}{|c|c|c|c|c|c|}
\hline \multirow[b]{2}{*}{ Question } & \multicolumn{5}{|c|}{ Response, n (\%) } \\
\hline & $\begin{array}{c}\text { Total } \\
(n=326)\end{array}$ & $\begin{array}{l}\text { D Pharm } \\
(n=101)\end{array}$ & $\begin{array}{c}\text { B Pharm } \\
(n=109)\end{array}$ & $\begin{array}{c}\text { Pharm D } \\
(n=116)\end{array}$ & p-value* \\
\hline $\begin{array}{l}\text { Have you studied about National Health Policy in your } \\
\text { pharmacy curriculum? } \\
\text { Yes } \\
\text { No } \\
\text { Do not know } \\
\text { Do not remember }\end{array}$ & $\begin{array}{c}96(30) \\
220(67) \\
7(2) \\
3(1) \\
\end{array}$ & $\begin{array}{c}25(25) \\
72(71) \\
2(2) \\
2(2) \\
\end{array}$ & $\begin{array}{c}13(12) \\
94(86) \\
1(1) \\
1(1)\end{array}$ & $\begin{array}{c}58(50) \\
54(47) \\
4(4) \\
0(0)\end{array}$ & $<0.001$ \\
\hline $\begin{array}{l}\text { Have you studied pharmaceutical policy in your pharmacy } \\
\text { curriculum? } \\
\text { Yes } \\
\text { No } \\
\text { Do not know } \\
\text { Do not remember }\end{array}$ & $\begin{array}{c}111(34) \\
197(60) \\
10(3) \\
8(3)\end{array}$ & $\begin{array}{c}31(31) \\
67(66) \\
0(0) \\
3(3)\end{array}$ & $\begin{array}{c}19(17) \\
84(77) \\
3(3) \\
3(3) \\
\end{array}$ & $\begin{array}{c}61(52) \\
46(40) \\
7(6) \\
2(2)\end{array}$ & $<0.001$ \\
\hline $\begin{array}{c}\text { Do you know the national public health programs in India? } \\
\text { Yes, I know well } \\
\text { Yes, I know to some extent } \\
\text { Yes, I have heard, but do not know contents } \\
\text { No, I have never heard about them }\end{array}$ & $\begin{array}{c}76(23) \\
100(31) \\
114(35) \\
36(11)\end{array}$ & $\begin{array}{l}17(17) \\
38(38) \\
29(29) \\
17(17)\end{array}$ & $\begin{array}{c}11(10) \\
31(29) \\
57(52) \\
10(9)\end{array}$ & $\begin{array}{c}48(41) \\
31(27) \\
28(24) \\
9(8)\end{array}$ & $<0.001$ \\
\hline $\begin{array}{l}\text { Have you received lectures or completed any courses that } \\
\text { provided information on national public health programs? } \\
\text { Yes, I have received lectures during my basic studies } \\
\text { Yes, I have received at least } 1 \text { course in continuing education } \\
\text { Yes, I have studied about NHPs as self-study } \\
\text { I have not received any training on national health programs }\end{array}$ & $\begin{array}{c}117(36) \\
13(4) \\
69(21) \\
127(39)\end{array}$ & $\begin{array}{c}25(25) \\
2(2) \\
16(16) \\
58(57)\end{array}$ & $\begin{array}{c}21(19) \\
5(5) \\
39(36) \\
44(40)\end{array}$ & $\begin{array}{c}71(61) \\
6(5) \\
14(12) \\
25(22) \\
\end{array}$ & $<0.001$ \\
\hline $\begin{array}{l}\text { Is the amount of time devoted to learn public health aspects } \\
\text { sufficient? (Basic pharmacy studies) } \\
\text { Yes, it is sufficient } \\
\text { No, not sufficient } \\
\text { No opinion }\end{array}$ & $\begin{array}{c}90(28) \\
166(51) \\
70(21) \\
\end{array}$ & $\begin{array}{l}27(27) \\
45(44) \\
29(29)\end{array}$ & $\begin{array}{l}36(33) \\
48(44) \\
25(23)\end{array}$ & $\begin{array}{l}27(23) \\
73(63) \\
16(14)\end{array}$ & 0.012 \\
\hline $\begin{array}{l}\text { Based on your pharmacy education, do you have adequate } \\
\text { knowledge to take part in national public health programs? } \\
\text { Yes } \\
\text { No } \\
\text { No opinion } \\
\text { Not necessary for pharmacists }\end{array}$ & $\begin{array}{c}188(58) \\
73(22) \\
59(18) \\
6(2)\end{array}$ & $\begin{array}{c}63(62) \\
23(23) \\
14(14) \\
1(1)\end{array}$ & $\begin{array}{c}49(45) \\
21(19) \\
34(31) \\
5(5)\end{array}$ & $\begin{array}{c}76(66) \\
29(25) \\
11(9) \\
0(0)\end{array}$ & $<0.001$ \\
\hline $\begin{array}{l}\text { Have you studied about disease prevention and dissemination } \\
\text { of information in National Public Health Programs? } \\
\text { Yes } \\
\text { No } \\
\text { Do not know }\end{array}$ & $\begin{array}{c}225(69) \\
91(28) \\
10(3)\end{array}$ & $\begin{array}{c}69(68) \\
28(28) \\
4(4)\end{array}$ & $\begin{array}{c}70(64) \\
36(33) \\
3(3)\end{array}$ & $\begin{array}{c}86(74) \\
27(23) \\
3(3)\end{array}$ & 0.539 \\
\hline $\begin{array}{l}\text { Is it necessary for the pharmacists to know about national } \\
\text { public health programs? } \\
\text { Yes } \\
\text { No }\end{array}$ & $\begin{array}{c}326(100) \\
0(0)\end{array}$ & $\begin{array}{c}101(100) \\
0(0)\end{array}$ & $\begin{array}{c}109(100) \\
0(0)\end{array}$ & $\begin{array}{c}116(100) \\
0(0)\end{array}$ & - \\
\hline
\end{tabular}

Chi-square test was used.

$\star p=<0.05$ was considered significant.

students believed that their current knowledge about NPHPs was very much sufficient or sufficient to become active part of NPHPs. However, 81\% students felt that they have very important or important role to play in NPHPs. Almost all, 96\% were willing to take up professional role in NPHPs and 81\% wanted to learn more on NPHPs. The proportion of students having been ever involved in any NPHPs during their pharmacy education program was highest for Pharm D students $(73 \%)$ and lowest for B Pharm students (28\%). The trend was the same concerning internships (51\% vs. $23 \%$, respectively).

\section{Perceived Knowledge in major National Public Health Programs in communicable diseases}

Of communicable diseases, most willingly students would take part in HIV/AIDS control $(83 \%$ of all respondents), Tuberculosis control (75\%), leprosy eradication programs and National Vector Borne Disease Control program (NVBDCP) (64\% of each) (Table 5). Of non-communicable diseases, $72 \%$ of the students were willing to take part in Blindness control, $76 \%$ pulse 
Table 4: Pharmacy students' ( $n=326)$ attitude on NPHPs - stratified by pharmacy program

\begin{tabular}{|c|c|c|c|c|c|}
\hline \multirow[b]{2}{*}{ Question } & \multicolumn{5}{|c|}{ Response, n (\%) } \\
\hline & $\begin{array}{c}\text { Total } \\
(n=326)\end{array}$ & $\begin{array}{l}\text { D Pharm } \\
(n=101)\end{array}$ & $\begin{array}{c}\text { B Pharm } \\
(n=109)\end{array}$ & $\begin{array}{c}\text { Pharm D } \\
(n=116)\end{array}$ & p-value* \\
\hline $\begin{array}{l}\text { Do you think that it is important to include National Public } \\
\text { Health Programs in normal training program for pharmacists? } \\
\qquad \begin{array}{c}\text { Very important } \\
\text { Important } \\
\text { Moderately } \\
\text { Of little importance } \\
\text { Unimportant }\end{array}\end{array}$ & $\begin{array}{c}186(57) \\
86(26) \\
45(14) \\
7(2) \\
2(1)\end{array}$ & $\begin{array}{c}70(69) \\
21(21) \\
6(6) \\
4(4) \\
0(0)\end{array}$ & $\begin{array}{c}50(46) \\
25(23) \\
32(29) \\
2(2) \\
0(0)\end{array}$ & $\begin{array}{c}66(57) \\
40(34) \\
7(6) \\
1(1) \\
2(2)\end{array}$ & $<0.001$ \\
\hline $\begin{array}{l}\text { Do you feel that your current knowledge about public health } \\
\text { programs in the country is sufficient? } \\
\text { Very much sufficient } \\
\text { Sufficient } \\
\text { Neutral } \\
\text { Not sufficient } \\
\text { Totally insufficient }\end{array}$ & $\begin{array}{c}14(4) \\
56(17) \\
64(20) \\
175(54) \\
17(5)\end{array}$ & $\begin{array}{c}3(3) \\
22(22) \\
31(31) \\
39(39) \\
6(6)\end{array}$ & $\begin{array}{c}4(4) \\
13(12) \\
12(11) \\
72(66) \\
8(7)\end{array}$ & $\begin{array}{c}7(6) \\
21(18) \\
21(18) \\
64(55) \\
3(3)\end{array}$ & 0.001 \\
\hline $\begin{array}{l}\text { Do you feel you have an important role to play in public health } \\
\text { programs? } \\
\qquad \begin{array}{c}\text { Very important } \\
\text { Important } \\
\text { Moderately } \\
\text { Of little importance } \\
\text { Unimportant }\end{array}\end{array}$ & $\begin{array}{c}176(54) \\
89(27) \\
24(8) \\
34(11) \\
0(0)\end{array}$ & $\begin{array}{c}60(59) \\
28(28) \\
10(10) \\
3(3) \\
0(0)\end{array}$ & $\begin{array}{c}42(38) \\
29(27) \\
8(7) \\
30(28) \\
0(0)\end{array}$ & $\begin{array}{c}77(66) \\
32(28) \\
6(5) \\
1(1) \\
0(0)\end{array}$ & $<0.001$ \\
\hline $\begin{array}{l}\text { During your pharmacy education program, have you ever been } \\
\text { involved in any public health program(s)? } \\
\text { Yes } \\
\text { No }\end{array}$ & $\begin{array}{l}156(48) \\
170(52)\end{array}$ & $\begin{array}{l}41(41) \\
60(59)\end{array}$ & $\begin{array}{l}30(28) \\
79(72)\end{array}$ & $\begin{array}{l}85(73) \\
31(27)\end{array}$ & $<0.001$ \\
\hline $\begin{array}{l}\text { Have you ever involved in any public health program(s) during } \\
\qquad \begin{array}{l}\text { your internship? } \\
\text { Yes } \\
\text { No }\end{array}\end{array}$ & $\begin{array}{l}134(41) \\
192(59)\end{array}$ & $\begin{array}{l}50(49) \\
51(51)\end{array}$ & $\begin{array}{l}25(23) \\
84(77)\end{array}$ & $\begin{array}{l}59(51) \\
57(49)\end{array}$ & $<0.001$ \\
\hline $\begin{array}{l}\text { Are you willing to take up a professional role in public health } \\
\text { program? } \\
\qquad \begin{array}{c}\text { Yes } \\
\text { No } \\
\text { Do not know }\end{array}\end{array}$ & $\begin{array}{l}252(77) \\
60(19) \\
14(4)\end{array}$ & $\begin{array}{c}86(85) \\
11(11) \\
4(4)\end{array}$ & $\begin{array}{c}71(65) \\
34(31) \\
4(4)\end{array}$ & $\begin{array}{c}95(82) \\
15(13) \\
6(5)\end{array}$ & 0.001 \\
\hline $\begin{array}{l}\text { Do you want to learn or learn more about Public Health } \\
\text { programs in your curriculum? } \\
\text { Yes } \\
\text { No } \\
\text { Do not know }\end{array}$ & $\begin{array}{l}263(81) \\
49(15) \\
14(4)\end{array}$ & $\begin{array}{c}91(90) \\
6(6) \\
4(4)\end{array}$ & $\begin{array}{c}68(62) \\
35(32) \\
6(6)\end{array}$ & $\begin{array}{c}104(90) \\
8(7) \\
4(3)\end{array}$ & $<0.001$ \\
\hline
\end{tabular}

Chi-square test was used.

$* p=<0.05$ was considered significant

polio programs and $67 \%$ in Universal Vaccination Program (Table 6). Under other programs prioritized as NPHPs (Table 6) $90 \%$ of the respondents were willing to take part in National Tobacco Control program and 60\% Program for Health Care of the Elderly.

\section{DISCUSSION}

The study results revealed that the participating pharmacy students were willing to learn about and take active role in NPHPs in India. All three pharmacy programs seem to introduce some basics of NPHPs in the studies, but more instruction is needed in all of them, particularly in

B Pharm program. Pharmacy students involved in this study prioritized to learn more about NPHPs during their pharmacy education, where pharmacists could contribute.

Overall results suggest students' positive overview on pharmacists' involvement in NPHPs. From the results, it is clear that both D Pharm and Pharm D students were showing more interest and were more motivated to learn about NPHPs than B Pharm students. This could be because D Pharm, but particularly newly designed clinically oriented Pharm D programs contain more theoretical and practical studies that prepare students for patient care than B Pharm which is industry ori- 


\section{Table 5: Perceived knowledge in major NPHPs in communicable diseases - stratified by pharmacy program} $(n=326)$

\begin{tabular}{|c|c|c|c|c|c|}
\hline \multirow[b]{2}{*}{ Question } & \multicolumn{5}{|c|}{ Response, n (\%) } \\
\hline & $\begin{array}{c}\text { Total } \\
(n=326)\end{array}$ & $\begin{array}{c}\text { D Pharm (n } \\
=101)\end{array}$ & $\begin{array}{c}\text { B Pharm } \\
(n=109)\end{array}$ & $\begin{array}{c}\text { Pharm D } \\
(n=116)\end{array}$ & p-value* \\
\hline
\end{tabular}

HIVIAIDS control program

NACO envisions an India where every person living with HIV has access to quality care and is treated with dignity. Effective prevention, care and support for HIVIAIDS is possible in an environment where human rights are respected and where those infected or affected by HIVIAIDS live a life without stigma and discrimination.

\begin{tabular}{|c|c|c|c|c|c|}
\hline $\begin{array}{c}\text { Do you know about the program? } \\
\text { Yes } \\
\text { No }\end{array}$ & $\begin{array}{c}293(90) \\
33(10)\end{array}$ & $\begin{array}{l}86(85) \\
15(15)\end{array}$ & $\begin{array}{c}101(93) \\
8(7)\end{array}$ & $\begin{array}{c}106(91) \\
10(9)\end{array}$ & 0.157 \\
\hline $\begin{array}{c}\text { Do you have a role to play? } \\
\text { Yes } \\
\text { No }\end{array}$ & $\begin{array}{c}245(75) \\
81(25)\end{array}$ & $\begin{array}{l}62(61) \\
39(39)\end{array}$ & $\begin{array}{l}81(74) \\
28(26)\end{array}$ & $\begin{array}{c}102(88) \\
14(12)\end{array}$ & $<0.001$ \\
\hline $\begin{array}{c}\text { Are you willing to take part? } \\
\text { Yes } \\
\text { No }\end{array}$ & $\begin{array}{c}269(83) \\
57(17)\end{array}$ & $\begin{array}{l}73(72) \\
28(28)\end{array}$ & $\begin{array}{c}100(92) \\
9(8)\end{array}$ & $\begin{array}{l}96(83) \\
20(17)\end{array}$ & 0.001 \\
\hline
\end{tabular}

Revised National Tuberculosis Control Program (RNTCP)

The objective of TB control Program is to achieve and maintain cure rate of at least $85 \%$ in new sputum positive pulmonary TB patients, and to achieve and maintain detection of at least $70 \%$ of such cases. Directly Observed Treatment is highlight of this program.

\begin{tabular}{|c|c|c|c|c|c|}
\hline Do you know about the program? & & & 0.005 \\
Yes & $255(78)$ & $71(70)$ & $82(75)$ & $102(88)$ \\
No & $71(22)$ & $30(30)$ & $27(25)$ & $14(12)$ \\
\hline Do you have a role to play? & $221(68)$ & $59(58)$ & $64(59)$ & $98(88)$ \\
Yes & $105(32)$ & $42(42)$ & $45(41)$ & $18(16)$ \\
\hline No & & & & \\
\hline Are you willing to take part? & $244(75)$ & $72(71)$ & $77(71)$ & $95(82)$ \\
Yes & $82(25)$ & $29(29)$ & $32(29)$ & $21(18)$ & 0.092 \\
No & & \\
\hline
\end{tabular}

National Vector Borne Disease Control program (NVBDCP)

The objective of the program is to prevent and control Malaria, Dengue, Lymphatic Filariasis, Kala-azar, Japanese Encephalitis and Chikungunya in India.

\begin{tabular}{|c|c|c|c|c|}
\hline $\begin{array}{c}\text { Do you know about the program? } \\
\text { Yes } \\
\text { No }\end{array}$ & $\begin{array}{l}211(65) \\
115(35)\end{array}$ & $\begin{array}{l}66(65) \\
35(35)\end{array}$ & $\begin{array}{l}63(58) \\
46(42)\end{array}$ & $\begin{array}{l}82(71) \\
34(29)\end{array}$ \\
\hline Do you have a role to play? & & & & \\
Yes & $186(57)$ & $52(51)$ & $53(49)$ & $81(70)$ \\
No & $140(43)$ & $49(49)$ & $56(51)$ & $35(30)$ \\
\hline Are you willing to take part? & & & \\
Yes & $210(64)$ & $68(67)$ & $62(57)$ & $80(69)$ \\
No & $116(36)$ & $33(33)$ & $47(43)$ & $36(31)$ \\
\hline
\end{tabular}

National Leprosy Eradication Program (NLEP)

Highlights of the program: Early detection \& complete treatment of new leprosy cases. Carrying out house hold contact survey

in detection. Early diagnosis \& prompt MDT, through routine and special efforts. Information, Education \& Communication (IEC) activities in the community to improve self reporting to Primary Health Centre (PHC) and reduction of stigma. Intensive monitoring and supervision at Primary Health Centre/Community Health Centre.

\begin{tabular}{|c|c|c|c|c|}
\hline Do you know about the program? & & & \\
Yes & $226(69)$ & $70(69)$ & $66(61)$ & $90(78)$ \\
No & $100(31)$ & $31(31)$ & $43(39)$ & $26(22)$ \\
\hline Do you have a role to play? & & & & \\
Yes & $203(62)$ & $54(53)$ & $57(52)$ & $92(79)$ \\
No & $123(38)$ & $47(47)$ & $52(48)$ & $24(21)$ \\
\hline Are you willing to take part? & & & & \\
Yes & $209(64)$ & $64(63)$ & $59(54)$ & $86(74)$ \\
No & $117(36)$ & $37(37)$ & $50(46)$ & $30(26)$ \\
\hline
\end{tabular}

Chi-square test was used.

${ }^{*} p=<0.05$ was considered significant. 
Table 6: Perceived knowledge in major NPHPs in non-communicable diseases and other areas - stratified by pharmacy program $(n=326)$

\begin{tabular}{|c|c|c|c|c|c|}
\hline \multirow[b]{2}{*}{ Question } & \multicolumn{5}{|c|}{ Response, n (\%) } \\
\hline & $\begin{array}{c}\text { Total } \\
(n=326)\end{array}$ & $\begin{array}{l}\text { D Pharm } \\
(n=101)\end{array}$ & $\begin{array}{l}\text { B Pharm } \\
(n=109)\end{array}$ & $\begin{array}{l}\text { Pharm D } \\
(\mathrm{n}=116)\end{array}$ & $p$-value \\
\hline \multicolumn{6}{|c|}{$\begin{array}{l}\text { National Mental Health Program (NMHP) } \\
\text { Objectives: } 1 \text {. To ensure the availability and accessibility of minimum mental healthcare for all in the foreseeable future, particularly } \\
\text { to the most vulnerable and underprivileged sections of the population; } 2 \text {. To encourage the application of mental health knowledge in } \\
\text { general healthcare and in social development; and } 3 \text {. To promote community participation in the mental health service development } \\
\text { and to stimulate efforts towards self-help in the community. }\end{array}$} \\
\hline $\begin{array}{c}\text { Do you know about the program? } \\
\text { Yes } \\
\text { No }\end{array}$ & $\begin{array}{l}213(65) \\
113(35)\end{array}$ & $\begin{array}{l}66(65) \\
35(35)\end{array}$ & $\begin{array}{l}61(56) \\
48(44)\end{array}$ & $\begin{array}{l}86(74) \\
30(26)\end{array}$ & 0.017 \\
\hline $\begin{array}{c}\text { Do you have a role to play? } \\
\text { Yes } \\
\text { No }\end{array}$ & $\begin{array}{l}178(55) \\
148(45)\end{array}$ & $\begin{array}{l}55(54) \\
46(46)\end{array}$ & $\begin{array}{l}49(45) \\
60(55)\end{array}$ & $\begin{array}{l}74(64) \\
42(36)\end{array}$ & 0.018 \\
\hline $\begin{array}{l}\text { Are you willing to take part? } \\
\text { Yes } \\
\text { No }\end{array}$ & $\begin{array}{l}217(67) \\
109(33)\end{array}$ & $\begin{array}{l}68(67) \\
33(33)\end{array}$ & $\begin{array}{l}61(56) \\
48(44)\end{array}$ & $\begin{array}{l}88(76) \\
28(24)\end{array}$ & 0.007 \\
\hline
\end{tabular}

National Program for Prevention and Control of Deafness (NPPCD)

Highlights: 1 . To prevent the avoidable hearing loss on account of disease or injury, 2. Early identification, diagnosis and treatment of ear problems responsible for hearing loss and deafness, 3 . To strengthen the existing inter-sectoral linkages for continuity of the rehabilitation programme, for persons with deafness.

\begin{tabular}{|c|c|c|c|c|c|}
\hline $\begin{array}{c}\text { Do you know about the program? } \\
\text { Yes } \\
\text { No }\end{array}$ & $\begin{array}{l}181(56) \\
145(44)\end{array}$ & $\begin{array}{l}53(52) \\
48(48)\end{array}$ & $\begin{array}{l}55(50) \\
54(50)\end{array}$ & $\begin{array}{l}73(63) \\
43(37)\end{array}$ & 0.129 \\
\hline $\begin{array}{c}\text { Do you have a role to play? } \\
\text { Yes } \\
\text { No }\end{array}$ & $\begin{array}{l}169(52) \\
157(48)\end{array}$ & $\begin{array}{l}53(52) \\
48(48)\end{array}$ & $\begin{array}{l}39(36) \\
70(64)\end{array}$ & $\begin{array}{l}77(66) \\
39(34)\end{array}$ & $<0.001$ \\
\hline $\begin{array}{c}\text { Are you willing to take part? } \\
\text { Yes } \\
\text { No }\end{array}$ & $\begin{array}{l}189(58) \\
137(42)\end{array}$ & $\begin{array}{l}43(43) \\
58(57)\end{array}$ & $\begin{array}{l}51(47) \\
58(53)\end{array}$ & $\begin{array}{l}80(69) \\
36(31)\end{array}$ & 0.001 \\
\hline
\end{tabular}

Highlights: 1. To reduce the backlog of blindness through identification and treatment of blind at primary, secondary and tertiary levels.

2. Prevention of visual impairment; through provision of comprehensive eye care services and quality service delivery. 3 . To enhance community awareness on eye care and lay stress on preventive measures; 4 . To secure participation of Voluntary Organizations/ Private Practitioners in eye Care

\begin{tabular}{|c|c|c|c|c|c|}
\hline $\begin{array}{c}\text { Do you know about the program? } \\
\text { Yes } \\
\text { No }\end{array}$ & $\begin{array}{c}238(73) \\
88(27)\end{array}$ & $\begin{array}{l}75(74) \\
26(26)\end{array}$ & $\begin{array}{l}86(80) \\
23(21)\end{array}$ & $\begin{array}{l}77(66) \\
39(34)\end{array}$ & 0.101 \\
\hline $\begin{array}{c}\text { Do you have a role to play? } \\
\text { Yes } \\
\text { No }\end{array}$ & $\begin{array}{l}213(65) \\
113(35)\end{array}$ & $\begin{array}{l}65(64) \\
36(36)\end{array}$ & $\begin{array}{l}71(65) \\
38(35)\end{array}$ & $\begin{array}{l}77(66) \\
39(34)\end{array}$ & 0.951 \\
\hline $\begin{array}{c}\text { Are you willing to take part? } \\
\text { Yes } \\
\text { No }\end{array}$ & $\begin{array}{c}234(72) \\
92(28)\end{array}$ & $\begin{array}{l}69(68) \\
32(32)\end{array}$ & $\begin{array}{l}87(80) \\
22(20)\end{array}$ & $\begin{array}{l}78(67) \\
38(33)\end{array}$ & 0.072 \\
\hline
\end{tabular}

Pulse Polio program

Objectives: Children in the age group of 0-5 years administered Polio drops during the national and sub-nationals immunization rounds. About 172 million children are immunized during each National Immunization Day.

\begin{tabular}{|c|c|c|c|c|}
\hline Do you know about the program? & & & \\
Yes & $260(80)$ & $70(69)$ & $92(84)$ & $98(84)$ \\
No & $66(20)$ & $31(31)$ & $17(16)$ & $18(16)$ \\
\hline Do you have a role to play? & $229(70)$ & $56(55)$ & $76(70)$ & $97(84)$ \\
Yes & $97(30)$ & $45(45)$ & $33(30)$ & $19(16)$ \\
\hline No & & & \\
\hline Are you willing to take part? & $248(76)$ & $65(64)$ & $87(80)$ & $96(83)$ \\
Yes & $78(24)$ & $36(36)$ & $22(20)$ & $20(17)$ \\
\hline No
\end{tabular}




\section{Table 6: Cont'd.}

Universal Immunization Program (UIP)

Objective: Protection of children from life threatening conditions by providing vaccination. Under UIP, following vaccines are provided: 1. BCG, 2. DPT, 3. OPV (Oral Polio Vaccine), 4. Measles, 5. Hepatitis B, 6. TT (Tetanus Toxoid), etc.

\begin{tabular}{|c|c|c|c|c|c|}
\hline Do you know about the program? & & & & 0.001 \\
Yes & $220(67)$ & $75(74)$ & $58(53)$ & $87(75)$ \\
$29(25)$
\end{tabular}

National Tobacco Control Program (NTCP)

Types of benefits of NTCP: 1. To bring about greater awareness about the harmful effects of tobacco use and about the Tobacco Control Laws and 2.To facilitate effective implementation of the Tobacco Control Laws.

\begin{tabular}{|c|c|c|c|c|c|}
\hline $\begin{array}{c}\text { Do you know about the program? } \\
\text { Yes } \\
\text { No }\end{array}$ & $\begin{array}{c}294(90) \\
32(10)\end{array}$ & $\begin{array}{l}88(87) \\
13(13)\end{array}$ & $\begin{array}{c}101(93) \\
8(7)\end{array}$ & $\begin{array}{c}105(91) \\
11(10)\end{array}$ & 0.399 \\
\hline $\begin{array}{c}\text { Do you have a role to play? } \\
\text { Yes } \\
\text { No }\end{array}$ & $\begin{array}{c}265(81) \\
61(19)\end{array}$ & $\begin{array}{l}73(72) \\
28(28)\end{array}$ & $\begin{array}{l}88(81) \\
21(19)\end{array}$ & $\begin{array}{c}104(90) \\
12(10)\end{array}$ & 0.005 \\
\hline $\begin{array}{c}\text { Are you willing to take part? } \\
\text { Yes } \\
\text { No }\end{array}$ & $\begin{array}{c}292(90) \\
34(10)\end{array}$ & $\begin{array}{l}85(84) \\
16(16)\end{array}$ & $\begin{array}{c}104(95) \\
5(5)\end{array}$ & $\begin{array}{c}103(89) \\
13(11)\end{array}$ & 0.027 \\
\hline
\end{tabular}

National Program for Health Care of the Elderly (NPHCE)

Objective is to provide separate, specialized and comprehensive health care to the senior citizens at various level of State health care delivery system including outreach services.

\begin{tabular}{|c|c|c|c|c|c|}
\hline $\begin{array}{c}\text { Do you know about the program? } \\
\text { Yes } \\
\text { No }\end{array}$ & $\begin{array}{l}171(52) \\
155(48)\end{array}$ & $\begin{array}{l}47(47) \\
54(53)\end{array}$ & $\begin{array}{l}42(39) \\
67(61)\end{array}$ & $\begin{array}{l}82(71) \\
34(29)\end{array}$ & $<0.001$ \\
\hline $\begin{array}{c}\text { Do you have a role to play? } \\
\text { Yes } \\
\text { No }\end{array}$ & $\begin{array}{l}176(54) \\
150(46)\end{array}$ & $\begin{array}{l}56(55) \\
45(45)\end{array}$ & $\begin{array}{l}34(31) \\
75(69)\end{array}$ & $\begin{array}{l}86(74) \\
30(26)\end{array}$ & $<0.001$ \\
\hline $\begin{array}{c}\text { Are you willing to take part? } \\
\text { Yes } \\
\text { No }\end{array}$ & $\begin{array}{l}197(60) \\
129(40)\end{array}$ & $\begin{array}{l}63(62) \\
38(35)\end{array}$ & $\begin{array}{l}46(42) \\
63(58)\end{array}$ & $\begin{array}{l}88(76) \\
28(24)\end{array}$ & $<0.001$ \\
\hline
\end{tabular}

Chi-square test was used.

${ }^{*} p=<0.05$ was considered significant.

ented program. As a consequence, D Pharm and Pharm D students may have more concrete understanding of NPHP-related work in clinical practice which may reflect to their positive responses. As D Pharm generally is the mainstay of pharmacy practice in India with over 42,000 admissions per year of the total of $100,000^{14}$ and Pharm $\mathrm{D}$ has been adding to it by providing about approximately 5,000 graduates with even more comprehensive clinical skills since $2008 .{ }^{15}$ It is important to focus on these two programs when developing pharmacists' competences in patient care and public health aspects. B Pharm curriculum is industry oriented with more pharmaceutical sciences and less pharmacy practice and patient care aspects. ${ }^{8}$

This study revealed a gap between pharmacy students' willingness to be involved in NPHPs and their perceived competencies to actually be involved in them. Findings of this study are in line with a systematic review from UK which showed that most pharmacists viewed public health services as important, but pharmacists' confidence in providing public health services was on the whole average to low. ${ }^{16}$ Pharmacy curriculum and training with better, well-designed focus on NPHPs would help future pharmacists to prepare better. Introduction of NPHPs to internship programs would also improve students' understanding of implementation of NPHPs in clinical practice and how pharmacists can contribute. There are encouraging results from USA indicating that time devoted to public health discussions during an Advanced Pharmacy Practice Experience (APPE) has substantial impact on pharmacy students' knowledgebase and interest in public health. ${ }^{17}$ 
HIV/AIDS control, RNTCP, Pulse Polio, NPCB and NTCP were top five National Public Health programs that the responding students knew about and felt that they have a role to play. In addition to these top five programs, more than $60 \%$ of the students showed interest in most of the other six programs involved in the survey. This means that if the pharmacists are trained in NPHPs, they can be utilized to supplement the limited health workforce in India in a wide range of public health concerns. The following paragraphs will briefly discuss pharmacists' potential contributions to those NPHPs that were ranked among top five by the responding pharmacy students.

\section{HIVIAIDS control program}

HIV/AIDS control program was the most well-known among the responding students. This may be because of Indian Pharmaceutical Association's (IPA) initiatives since 2000 in creating awareness on the roles and opportunities for pharmacists in HIV/AIDS care and prevention. Among the initiatives there has been National Pharmacy Week 2000 with the theme "Pharmacists to fight against HIV/AIDS"; prepared "guiding principles for pharmacists"; ${ }^{18}$ trained -trainers, in-service pharmacists, and training programs in schools. IPA had also several endorsements and statements to promote pharmacists role in HIV/AIDS. WHO-India recommended integrating pharmacists in National AIDS Control Organization's (NACO) programs such as in procurement, storage, distribution and proper use of Antiretroviral ARV medicines. ${ }^{19}$ In line with this, as a mandatory training, pharmacists working in Antiretroviral Therapy (ART) centers and Link ART centers (LAC) were being trained by the Department of AIDS Control. ${ }^{20}$ An extension of such training for pharmacists working in private pharmacies and students/interns would increase the impact in several folds, which is supported by $83 \%$ percent of students' interest to take active part in HIV/AIDS Control program.

\section{Revised National Tuberculosis control program (RNTCP)}

Eighty three percent of the responding students were willing to take part in RNTCP. According to a previous research, pharmacists can be key players in prevention and treatment of tuberculosis by promoting adherence, assessing patients for risk factors for resistant disease, providing information about disease control and prevention, and monitoring for effectiveness, adverse effects, and drug interactions. ${ }^{21}$ Private pharmacies play a key role in influencing patients' treatment choices and in guiding them to appropriate health care facilities. ${ }^{22}$ Providing continuing education on TB control to diploma-trained community pharmacists can improve case detection and rational use of anti-TB medicines. ${ }^{23}$ Because of which, Ministry of Health took a step forward in utilizing the community pharmacies and pharmacist workforce by preparing a training module for community pharmacists jointly with IPA. ${ }^{24}$ For the first time in 2010, RNTCP guidelines mentioned "pharmacists" as specialists with expertise in managing Multi-Drug-Resistant Tuberculosis (MDR-TB), ${ }^{25}$ which is very motivating for the pharmacy profession in the country.

\section{Pulse Polio and Universal Immunization Programs}

Eighty percent of the respondents knew Pulse Polio and Universal Immunization programs and about $70 \%$ were willing to take part in these programs. National Vaccine Policy suggests that it is important to have experts from pharmacy to reduce time lag from availability of a vaccine to its use in National Immunization Programs. ${ }^{26}$ Internationally, the provision of immunisation services involving pharmacists trained and certified to administer vaccines, utilising agreed protocols and collaborative arrangements, is now well accepted in countries such as the USA, UK, Ireland and Portugal, ${ }^{27}$ such success stories can be adopted by pharmacists in India to take initiatives to create evidence to become part of health care team.

\section{National Tobacco Control Program (NTCP)}

In this survey, $90 \%$ of the responding pharmacy students were willing to take active role in Tobacco Control. This is quite similar result as was obtained in a previous study in $2003(92.5 \%){ }^{28,29}$ This acknowledges that pharmacists have a continuous interest in promoting smoking cessation. Smoking is among the most important risk factors jeopardizing public health, and thus, pharmacists' are easily accessible healthcare professionals to be involved in NTCP. Potential for Indian pharmacy students and pharmacists to make a definitive contribution to public health protection though NTCP should be utilized by the government of India.

\section{National Program on Control of Blindness (NPCB)}

Though $72 \%$ of the responding students showed enthusiasm to take active role in NPCB, there is no documented evidence on pharmacist involvement in NPCB as there is on HIV/AIDS control program, RNTCP and NTCP. Therefore, it is important to take initiatives by the professional bodies to find out how pharmacists can contribute in NPCB and create evidence. 
The above experiences and examples show that there are many ways that the Indian government can utilize pharmacists' expertise in different public health programs. As pharmacy students seem to be interested in contributing to NPHPs, it is important that professional organizations, such as IPA and the Pharmacy Council of India will cooperate with pharmacy schools in curriculum development and shaping new public health roles and services for pharmacists. The Pharmacy Council of India, responsible statutory body for regulation of profession and practice of pharmacy, is also promoting pharmacists' role in public health. ${ }^{30}$

\section{STUDY LIMITATIONS}

The strength of this classroom survey was that there is equal number of participants from the three different pharmacy programs. Classroom survey method facilitates inclusion of all students which decreases the influence of selection bias on results.

One of the major limitations is the number of colleges and students' participation, as the study was limited to five colleges in south India. As the study was conducted only in South India, it can be considered as a pilot study to test the method and get some insights in pharmacy students' knowledge and attitude on NPHPs. A national level study with larger random sample of students from entire India would give more insights to the situation. Every year, there is a possibility for over 100,000 admissions in over 1800 pharmacy colleges in India. ${ }^{8}$ Reaching all these students to organize such a large study by using random sampling would only be possible by taking initiatives by Pharmacy Council of India or Indian Association of Colleges of Pharmacies and using their network. Such a large study would be useful for the professional bodies to start negotiations with policy makers to include pharmacists in national health policies, NPHPs and make them part of health care team.

\section{CONCLUSION}

Students had positive attitudes on pharmacists' involvement in NPHPs, although their attitudes varied in different student groups, Pharm D and D Pharm students being most positive towards pharmacists' involvement. The study also revealed the need for increasing contents supporting NPHPs to all pharmacy programs, particularly to B Pharm program. There is a scope for a national lever study for more detailed analysis to identity pharmacists as potential contributor within NPHPs.
The responding pharmacy students had the opinion that it is important for pharmacists to take part in national health policies and NPHPs. However, they are not learning enough about NPHPs and health policies in the pharmacy programs in India. This pilot study indicates that there is a scope for a national level survey for more detailed analysis to identity pharmacists as potential contributors within NPHPs, with particular reference to their role in HIV/AIDS control, RNTCP, Blindness control, pulse polio, NTCP, and universal vaccination, programs. Curriculum development teams and statutory authorities in India should start thinking of including public health aspects, national public health programs, in curricula at all levels.

If pharmacists can be included in National Health and Pharmaceutical Policies and supported to be important part of national public health programs, it is likely that increased exposure to public health services will have a positive effect of the attitudes and health of the general public. As it is suggested in WHO resolution WHA 47.12, it is high time to recognize the key role of pharmacists in public health care which should reflect to curriculum content. ${ }^{31}$

\section{WHAT THIS STUDY ADDS:}

1. This is the first published study to explore pharmacy students' acquaintance with 11 major National Public Health Programs (NPHPs) and their attitude on pharmacists' involvement in public health and patient care in India.

2. This study can be useful for guiding actions to include pharmacists in national health policies and make them part of health care team in different national public health programs.

3. In addition to benchmarking, the study could be pertinent for academicians and policymakers in India, as well as other countries where the role of the pharmacist is continuing to evolve towards inclusion of direct public health and patient care.

\section{ACKNOWLEDGEMENTS}

We wish to thank all the participating students from various colleges and Dr. A. Rajasekaran, Dr. Grace Rathnam, Dr. G. Arihara Sivakumar, Dr. B. Senthil Kumar, Dr. D. C. Premanand, India; Dr. Loganathan Veerappan, Taylor's University, Malaysia for their assistance in data collection and during the preparation of this article. 


\section{SUMMARY}

- A survey tool was prepared and distributed to 326 students to explore the awareness, perceived knowledge and attitude of Indian pharmacy students on National Public Health Programs.

- $96 \%$ were willing to take up a professional role and want to learn more about NPHPs.

- Students had positive attitudes on pharmacists' involvement in NPHPs, although their attitudes varied in different student groups, Pharm D and D Pharm students being most positive towards involvement in NPHPs.

\section{About Authors}

Siva Prasada Reddy, born on $20^{\text {th }}$ April 1975 in India. He is currently pursuing PhD from University of Helsinki, Finland and working as Managing Pharmacist at Taastrup Pharmacy, Denmark. He served as Professional Secretary, FIP-WHO South East Asian Pharmaceutical Forum till 2008. He has 12 national and international publications and made several presentations at professional Congresses. He is qualified pharmacist from India, Denmark and has FPGE Certification from USA.

Marja Airaksinen is Vice Dean (Public Affairs) and Professor of Social Pharmacy in the Faculty of Pharmacy at the University of Helsinki, Finland. She has been involved in several patient information development programmes nationally and internationally, e.g., in the WHO/EuroPharm Forum and the Drug Information Division at the United States Pharmacopeia (USP). During 2000-2008, she was an Executive Committee Member of the Pharmacy Information Section in the International Pharmaceutical Federation (FIP). She has been involved in different national working groups on patient and medication safety under Ministry of Social Affairs and Health.

Dr. Peter Kielgast, born on $14^{\text {th }}$ Maj 1945, is currently Proprietor Pharmacist, Taastrup Pharmacy, Denmark. He served as Director General of Pharmacy Owners Association of Denmark. He was elected as President of the Pharmaceutical Group of the European Union in 1986, International Pharmaceutical Federation in 1998. He also served in other international Committees e.g. the Accreditation Council for Pharmacy Education (ACPE), Chicago, USA. He was awarded Honorary Doctorate from Mercer University, USA and luliu Hatieganu University, Romania.

\section{ETHICAL APPROVAL}

None sought, according to the ethics guidelines at the University of Helsinki ethical approval is not required for this kind of studies.

\section{Financial Disclosure Statement}

For this study and preparation of the manuscript the authors have not received any financial support from any profitable or non-profitable organizations.

\section{CONFLICT OF INTEREST}

The authors contributing to this study and manuscript have no conflict of interests.

\section{ABBREVIATION USED}

NPHPs : National Public Health Programs

FIP : International Pharmaceutical Federation

NRHM : National Rural Health Mission

WHO : World Health Organization

\section{REFERENCES}

1. Chen L, Evans D, Evans T, Sadana R, Stilwell B, Travis P, et al. World Health Organization (WHO): Working Together for Health: The World Health Report 2006. Geneva: WHO; 2006. Available at http://www.who.int/whr/2006/ whr06_en.pdf?ua=1 (accessed October 19, 2014).
2. Purohit B, Bandyopadhyay T. Beyond job security and money: Driving factors of motivation for government doctors in India. Hum Resour Health. 2014; 12(1):12.

3. Rao M, Rao KD, Shiva Kumar AK, Chaterjee M, Sundararaman T. Human resources for health in India. Lancet. 2011; 377(9765): 587-98.

4. Wledenmayer K, Summers R, Mackle C, Gous A, Everard M. Geneva and The Hague: World Health Organization. International Pharmaceutical Federation. Developing pharmacy practice: a focus on patient care. 2006 http://www.fip.org/files/fip/publications/DevelopingPharmacyPractice/ DevelopingPharmacyPracticeEN.pdf. Accessed October 18, 2014.

5. Basak SC, Sathyanarayana D. Community Pharmacy Practice in India: Past, Present and Future. Southern Med Review. 2009; 2(1): 11-4.

6. Pharmacy Council of India. Approved colleges - Diploma, Degree institutions and PharmD.http://www.pci.nic.in/CollegesCourses/ApprovedDiplomainstitutions us12.aspx and http://www.pci.nic.in/CollegesCourses/ApprovedDegree institutionsus12.aspx and http://www.pci.nic.in/CollegesCourses/Baccalaur eate.aspx. Accessed October 18, 2014.

7. Maddirala Venkata SPR, Kielgast $P$, Udhumansha $U$, Airaksinen M. Public Health and Patient Care Aspects in Indian Pharmacy Curriculum: A Comparison between D Pharm, B Pharm and Pharm D Programs. Curr Pharm Teach Learn. 2015; 7(1): 84-93.

8. Wledenmayer K, Summers R, Mackle C, Gous A, Everard M. Geneva and The Hague: World Health Organization, International Pharmaceutical Federation. Developing pharmacy practice: a focus on patient care. 2006. http://www.fip.org/files/fip/publications/DevelopingPharmacyPractice/ DevelopingPharmacyPracticeEN.pdf. Accessed October 25, 2014.

9. Department of Health and Family Welfare, Ministry of Health and Family Welfare, Government of India, New Delhi, India. http://mohfw.nic.in/index4 php?lang=1\&level=0\&linkid=316\&lid=1610. Accessed: November 01, 2014

10. Subal C B, Sathyanarayana D. Pharmacy education in India. J Pharm Educ. 2010; 74(4): 68.

11. Mohan Rao, Krishna D Rao, A K Shiva Kumar, Mirai Chatterjee, Thiagarajan Sundararaman. India: Towards Universal Health Coverage 5-Human resources for health in India. Lancet. 2011; 377(9765): 587-98. 
12. Chua GN, Hassali MA, Shafie AA, Awaisu A. A survey exploring knowledge and perceptions of general practitioners towards the use of generic medicines in the northern state of Malaysia. Health Policy. 2010; 95(2): 229-35.

13. Holtzman CW, Sifontis NM. Pharmacy students' perspectives on a PharmD/ MPH dual degree program at a large metropolitan school of pharmacy. Pharmacy Practice 2014; 12(1): 359.

14. Merlin NJ. Pharmacy careers: an overview. Asian J Pharm Sci. 2011; 1(1): 1-3.

15. Harkishan S. Pharmaceutical education and pharmacy practice: a historical perspective. Pharma Times. 2009; 41(2): 16-8.

16. Eades CE, Ferguson JS and O'Carroll RE. Public health in community pharmacy: A systematic review of pharmacist and consumer views. BMC Public Health. 2011; 11(1): 582.

17. Whitley H P. A Public Health Discussion Series in an Advanced Pharmacy Practice Experience. Am J Pharm Educ. 2010; 74 (6): 101.

18. Sheth PD, Frokaer B. Guiding principles for pharmacists in the fight against HIVIAIDS in India. Presented at Second International Conference on Improving use of Medicines. Chiang Mai, Thailand; 2004. <http://www.icium. org/icium2004/resources/ ppt/HI006.pdf>; Accessed january 23, 2015.

19. Sheth PD, Reddy MVSP, Vaidya R, Gharat M, Revikumar KG, Mondal S, et al. A Report on Challenges \& Opportunities for Pharmacists in Health Care in India. WHO-India Country Office and South East Asian FIP-WHO Forum of Pharmaceutical Associations; 2007. http://www.searpharm.org/resources/ PDF_files/Annual_reports/2008_SEARPharm\%20Forum\%20Report\%20 April\%202008.pdf. Accessed January 27, 2014.

20. National AIDS Control Organization (NACO), Department of AIDS Control. Care, Support and Treatment, National AIDS Control Programme, Phase-III, India.<http://www.naco.gov.in/upload/IEC\%20Division/NACO\%20monographs \%20for\%20Vienna/ART\%20Monograph.pdf> Accessed December 5, 2014.

21. Mitrzyk BM. Treatment of extensively drug-resistant tuberculosis and role of the pharmacist. Pharmacotherapy. 2008; 28(10): 1243-54.

22. Ananthakrishnan R, Krishnan N, Augustine S. PP-205 Private pharmacies in tuberculosis control: a survey to explore possibility of involving pharmacists in DOTS program in Chennai, India. Abstracts of 3rd Ditan International Conference on Infectious Diseases. Int. J. Infect. Dis. 2009: 13(1): 104

23. Gharat MS, Bell CA, Ambe GT, Bell JS. Engaging community pharmacists as partners in tuberculosis control: A case study from Mumbai. Res Soc Admin Pharm. 2007; 3(4): 464-70.

24. Ministry of health and family welfare. Government of India and Indian Pharmaceutical Association. REVISED NATIONAL TUBERCULOSIS CONTROL PROGRAMME - Training module for community pharmacists, 2013. <http://www.pci.nic.in/Circulars/Training\%20Module.pdf> Accessed December 16, 2014

25. Central TB Division, Directorate General of Health Services. Revised National Tuberculosis Control Program. DOTS-plus Guidelines. 2010. http://tbcindia.nic. in/pdfs/DOTS_Plus_Guidelines_Jan2010.pdf. Accessed February 28, 2014.

26. National Vaccine Policy. Ministry of Health and Family welfare. Government of India, 2011.

27. Community Pharmacy roadmap program development template, The Pharmacy Guild of Australia. http://www.guild.org.au/docs/default-source/ public-documents/tab---the-guild/strategic-direction/vaccine-administration. pdf?sfvrsn=0 Accessed April 28, 20015.

28. Reddy MVSP, Sheth PD. Pharmacist for promoting a future free of tobacco in India. FIP World Congress 2004, New Orleans, USA. www.fip.org/ projectsfip/pharmacistsagainsttobacco/NO5Reddy.pdf. Accessed January 23, 2015.

29. World Health Organization. The role of heath professionals in Tobacco Control. Health Professionals against Tobacco. 2005. http://www.who. int/tobacco/resources/publications/wntd/2005/bookletfinal_20april.pdf> Accessed January 232015.

30. Indian Pharmaceutical Association and Pharmacy Council of India. A caree in pharmacy. <http://www.ipapharma.org/news/Career\%20Booklet.pdf> 2009. Accessed April 28, 2015.

31. Forty-Seventh World Health Assembly. Resolution WHA 47.12, Role of the pharmacist in support of the WHO revised drug strategy. http://www. europharmforum.org/file/7412. Accessed October 18, 2014. 